\title{
An Assessment of Indian Writing in English as a Source for Learning English in Rural India
}

\author{
Sandeep K. Thorat \\ Department of English, S. S. S. K. R. Innani College, Karanja Lad, Dist. Washim Maharashtra, India \\ Email: sandeepk_thorat@rediffmail.com
}

\begin{abstract}
The vogue of English has given rise to the emergence of a new learner whose demands and ambitions are much more based on his interest than those of his counterpart in the past. Teaching English through Indian Writing in English (IWE) as source material may certainly meet the needs of learners in rural India. Teaching English through IWE is possible because it caters to the learner's interest and liking in rural India. A textbook should be designed in respect to meet the needs of the learner. The learner becomes passive participant when the textbook is against his will and liking. "Even today, in quite a few states even at the intermediate/higher-secondary/first year B. A. level, poems by Keats: La Belle Dame Sans Merci (neither the teacher nor the students can pronounce even the title properly), Wordsworth's Daffodils (which nobody has seen in India) or poems about the courtly love games of the idle European feudal classes like To His Mistress by Andrew Marvell are prescribed (N. and Lalita Krishnaswamy, 2003)". Thus, a textbook that does not respond to the liking and interest of a learner can prove a total failure.
\end{abstract}

Index Terms - Indian writing in English, source material, rural India

\section{INTRODUCTION}

This paper states that Indian Writing in English (IWE) can be a source for teaching and learning English in rural India at under graduate level. This innovative method of learning English can be beneficial for several reasons. In first place, many Indians in rural areas are strictly related to traditional belief systems; secondly, their identity is rooted in the pride of being Indian and in such condition it becomes more important to love what is Indian; thirdly, the learners from rural parts can perform well in other subjects like History, Economics, Political Science, Sociology and others. These subjects offer them the materials from Indian scenes, situations and milieus, which seem to be the point of their attraction (Appendix-A). On the other side, in the present era, the significance of English Language has increased more than ever. Everyone, today, is eager to acquire the knowledge and competency of English to stay ahead in this competitive world. English performs a key role in all lifestyles today. Broadly speaking, English has been accepted by almost all the Universities in India as a significant medium of Education. In such situations, teaching English effectively and interestingly has become more important than ever. In fact, IWE can prove as an effective source for learning English.

\section{PRECONDITION OF ENGLISH IN INDIA}

English came to Indians as the language of the oppressors and decorated the Indian crown of glory, prestige and dignity. Today, English has entered the hearts and minds of Indians and become the part and parcel of Indian culture. It took long period for Indians to give a native identity to English language. On the other hand, the second language status of English in Indian educational system has prevailed nearly for half and a century. Considering the importance, place, status of English at international level, the young generation of India is fascinated by its use in all spheres of everyday situation. Especially, learners in rural India have recognized that the knowledge of English provides lots of prospects and opportunities. Nowadays, English has become the concrete means of livelihood of millions.

Indians are interested to reflect their culture and civilization of which they are proud of by inculcating the skill of this language. Basically, India is a land of a wide variety of religion, castes, attitudes, traditions, superstitions and beliefs. Therefore, Indians want to mould English on their own soil with a self-stamp. In such conditions, a question arises in the mind that can Indian Writing in English be an effective tool for teaching English?

British Rule brought English in India and percolated it in Indian society when Lord Macaulay introduced it for the first time by establishing Educational institutes. Indians, by and gradually, were attracted to it and with the passage of time they started reading, speaking and comprehending English. They began writing in English too. Ample of literary forms have been handled by Indian writers writing in English. Thus, English flourished at the hands of different writers who wrote in various forms such as novels, dramas, poetry, short stories etc. In fact, they earned a separate identity to their literature and coined some terms like Indo-Anglian, Indo-English, Indian English, and Indian literature, Indian writing, Indian fiction, and Indian poetry in English etc. 
Like American, African, Canadian, English Literature, Indian English Literature is a sincere attempt to represent India. The explosion of English in India formed a new generation and voice in which Indians speaks. Since Indian Renaissance, Indian writers writing in English have been making manifold contribution to the World literature.

\section{THE FOUNDERS OF IWE}

Of course, the line of founders of Indian Writing in English is too long to list here. However, starting from Ram Mohan Roy, Vivekananda, Ramatirtha, Henry Louis Vivan Derozio, Kashiprosad Ghose, Michael Madhusudan Dutt, Toru Dutt, Sri Aurobindo, R. Tagore, Gandhi, Radhakrishnan, Sarojini Naidu, R. K. Narayan, Raja Rao, Manohar Malgaonkar, Mulk Raj Anand, Khushwant Sing, Nissim Ezekiel, Vijay Tendulkar, A. K. Ramanujan, Kamala Das, Arun Kolatkar, Anita Desai, Girish Karnad, Vikram Seth, Shashi Deshpande, Salman Rushdie, Shoba De, Rohinton Mistry, Amitav Ghosh, Kiran Desai, Arundhati Roy, Jhumpa Lahiri, Namita Gokhale and many more contributed to Indian Writing in English.

Born in India, most of these writers wrote in English having their command on the native languages. It is really a challenging task to show commanding mastery on non-native language despite of their command on mother tongues. Initially, they were hardly sure to write on Indian subjects in English. But Englishmen like Sir William Jones, John Leyden, Sir Edwin Arnold, Meadows Taylor, F. W. Bain and many more lived in India for many years and wrote on Indian subjects in English. In fact, these Anglo-Indians cleared the way for Indians to consider English fit for Indian subjects. Indian Writing in English (IWE) is a sincere record of the rare gems of Indian situations, experiences, traditions and milieus. However, these traits in IWE can attract the attention of learners and prove helpful for learning English.

\section{WORTH OF IWE AS A SOURCE MATERIAL FOR LEARNING ENGLISH}

Almost each work in IWE has enough potential to impress an Indian sensibility. Indian subjects and themes may attract the attention of Indian learners and teachers of English. Tagore wrote primarily in Bengali, but due to his command over English, he translated many of his plays and poems into English. His Chandalika (1933) expresses his love for Buddhism and the Buddha as a spiritual power. Prakriti, the untouchable girl, falls in love with Ananda, the Buddha's best loved disciple. But Ananda has gone away. Prakriti asks her mother to apply spell on him so that he may return to her. He is brought to her hut but at the same time his face becomes ugly due to wrong procedure. Prakriti's victory becomes her defeat. She cries in despair and again asks her mother to release him from spell. Thus, the stress is on the spiritual action. Prakriti and her mother feel the transforming power of the pure in heart. Ananda feels angelic in compassion. This purification is only possible in the spiritual realm. Gitanjali (1912) is a devotional poetry by Tagore. It is written in Indian bhakti tradition. It is half a prayer from below and half a whisper from above. It reflects the basic experience, the longing, the trial, the promise, the realization. It is a record of Indian flavour and taste.

Sarojini Naidu's first collection of poems, The Golden Threshold, came out in 1905. In her poem Palanquin Bearers, the newly married bride is being carried in a palanquin to her husband's house. The bearers are singing a traditional folk song expressing two phases of her life - sorrow of departure and joy at the prospect of a new life. Indian sensuousness, various facets of Islam, patriotic note, various Indian festivals are found in her different poems.

R. K. Narayan's Swami and Friends is the story of ten-years old boy, Swaminathan, full of joy, innocence, wonder and mischief, and his experiences growing up in the fictional town of Malgudi. The story begins with Swami, attending his monotonous schooling in Albert Mission School. Rajam, son of a police officer joins his school and the dispute that occurs between Rajam and Mani who is also Swami's friend and thereafter the steady friendship between Swami, Rajam and Mani. The novel expresses conflict between Indian and Western culture. It chronicles an extroverted Schoolboy's rebellion against his missionary upbringing. His characters are ordinary people who rely on Hindu principals.

Raja Rao's Kanthapura (1938) reflects Gandhi's impact on a South Indian Village through the chatty language of an elderly widow. The story-teller is a grandmother. Of course, the art of story telling is second nature to the Indian grandmother. Mulk Raj Anand's The Untouchable (1935) describes the problem of the rooted untouchability. The narrative begins with the description of outcaste colony - a group of mud walled houses outside the town - which is a symbol of traditional practice of untouchability. Bhakha, the protagonist, hates his lot. He is humiliated even in upper class Hindu colony. Nissim Ezekiel has written a collection of Very Indian Poems in Indian English. His poem Goodbye Party for Miss Pushpa T.S. reflects the syntactical oddities of Indian English. The poem tries to depict the characteristic Indian attitudes in Swadeshi Angrezi. He employs present continuous tense instead of simple present. His faulty use of indefinite articles and the use of no to enforce a point show typical Indian attitude.

A. K. Ramanujan's first volume of English poems The Striders appeared in 1966. His A River, a poem is on the river Vaikai which flows through Madhurai. Every summer it dries to a tricle and no one speaks about pitiable loss of life. They sang only of the floods, but not about human beings. The poem reveals the materialistic attitude of the modern minds. Another outstanding poet is Kamala Das who published her autobiography My Story in 1976. The predominant theme of My Story is the difficulty of being a woman in Indian society and finding love in the institution of the arranged 
marriage. She felt a sense of loneliness which continued in her married life where she faced a male - oriented world of sex and lust.

Vijay Tendulkar's Sakharam Binder (1972) remains his outstanding play for its bold societal theme of the male dominating the female in every sphere of life. Sakharam, a bookbinder, takes in a succession of women who have been thrown out of their homes by their husbands. He offers them food and shelter in exchange for domestic services. He fiercely opposes the hypocrisy in the institution of marriage. Though he takes pride in the forthright nature of these unions, he is ultimately overpowered the potent and sometimes violent force of the bonds that develops.

In Anita Desai's Fasting, Feasting (1999), Uma, a daughter without look and talent, is ill-treated by her parents who overlook the aspirations of their daughter and pay attention on their only son. She has to stop her study in order to look after her baby brother Arun. It relates the disastrous attempts of an Indian daughter to leave her parents' home and achieve independence without marriage. Vikram Seth's A Suitable Boy (1993) deals with the search for a suitable bridegroom by Mrs. Rupa Mehara for her daughter. Her search ends when her daughter meets Haresh Khanna. Beyond match making, the novel further deals with the social panorama of the decade. The stories of different families are gathered to create this panorama. Further, the novel gives rise to the discussion on the Zamindari Abolition Bill, religious festivals and rituals etc.

In Shashi Deshpande's That Long Silence (1988), the narrator Jaya, an upper middle class housewife in Bombay, with two teenage children, is forced to take stock of her life when her husband has been caught in malpractice. As a result, they shift into their old house in Dadar. She remembers her past happy days and feels unsatisfied with her married life. Now she becomes a very submissive woman and longs to be called an ideal wife. She now has only silence and surrender.

Mahesh Dattani's Final Solution first performed in Banglore in 1993. It foregrounds the Hindu-Muslim problems. Dattani could not find final solution to these problems of communial riots, disputes and hatred. The novel also deals with the theme of transferred resentments in the context of family relations. Smita, unable to express her love for Babban, criticizes her mother bitterly. She hates praying and fasting. Her mother accuses her of running away from religion. The characters in the play are shown expressing their anger at every stage.

A glimpse into the works of Indo-Anglian writers shows the reflection of Indian ethos and milieu which can touch the hearts of Indians and win their appreciation. In addition, a study of such and other works may be of great help to the teachers and the learners of English. Therefore, it is essential to see that such Indian ethos and milieu really attract the attention of Indians and teaching English through IWE may be possible.

\section{THE LOCATION OF THE RESEARCH}

To meet the objectives of the research, the entire investigation has been carried out on certain methodology. The location of the research is the colleges affiliated to Sant Gadge Baba Amravati University, Amravati, Maharashtra, India where most of the colleges are located in rural areas. A well- planned Questionnaire has been prepared to see that whether teaching English through IWE may be possible or not.

\section{TEACHERS' AND LEARNERS' RESPONSE}

The paper earnestly attempts to find teachers' and learners' response to IWE and an assessment of its worth as a source for teaching and learning English on the basis of a questionnaire applied at UG level in near about twenty colleges affiliated to Sant Gadge Baba Amravati University, Amravati, Maharashtra, India. With the help of the above mention questionnaire, 40 teachers and 60 learners at under graduate level in total 20 colleges have been found responding affirmatively to teach and learn English through IWE (Appendix- A \& B). In fact, from the above mentioned survey, the response of the teachers and learners to teach English through IWE is positive to some extent. Hence, IWE may serve as an effective tool for teaching and learning English in rural India.

\section{CONCLUSION}

The paper analyzes founders of IWE in order to know the value of English in India to non-native speakers in the beginning and how they begin to learn English. It seems that Indians succeed in the aim. Then it can be possible to learn English through IWE in rural India to some extent. IWE reflects Indian ethos and milieu which can touch the hearts of Indian readers for only native can feel these ethos and milieu. The learners can perform well when the text offers them the material of their interest and liking. They can do well in English like other subjects (Appendix-A). Moreover, a study of such and other works may be of great help to the teachers and learners of English.

Besides, Meditation, contemplation and reflective thinking have always been encouraged in learning English. To create a proper environment and encourage critical interaction with text is essential to develop critical thinking and contemplative power among learners. Learner from rural India can think and contemplate in English when he is given the text of his liking especially a text from IWE (Appendix-A). The meditation done in this way makes permanent impression upon the mind of the learner and leads him to that state of mind where he has ample chances to learn English. 


\section{APPENDIX A QUESTIONNAIRE FOR LEARNERS}

[1] Name

[2] Class (in which you are studying presently)

[3] Your Birth Place

[4] Where are you studding presently? (Town/village)

(Town/village)

[5] Do you like to attend the English class regularly? Yes/No

[6] Which class do you like to attend regulsrly? [Please tick mark]

O History O Sociology O English O Other

[7] Which text does help you most to comprehend the knowledge of English? (Below are given the names of literatures Indo-Anglian and English. Rate your preference on a three-point scale: Very Well 1, Well 2, a little 3. Put a circle round the number that applies to you)

$\begin{array}{lccc}\text { Text } & \text { Very Well } & \text { Well } & \text { A Little } \\ \text { British Literature } & 1 & 2 & 3 \\ \text { Indian English Literatue } & 1 & 2 & 3 \\ \text { American Literature } & 1 & 2 & 3\end{array}$

[8] Which following poet do you like to read most? [Please tick mark]

O Robert Frost O William Wordsworth O Nissim Ezekiel

[9] Do you find it easy to learn English through IWE?

Yes $(\ldots \ldots \ldots) \quad$ No $(\ldots \ldots \ldots . .$.$) \quad I don't know (\ldots \ldots \ldots)$

\section{APPENDIX B QUESTIONNAIRE FOR TEACHERS}

[1] Name

[2] Classes to which you are teaching presently ............

[3] Your Birth Place (Town/village)

[4] Where are you teaching presently?

........................... (Town/village)

[5] Which text does create more interest and enthusiasm among the learners while teaching English? (Below are given the names of literatures Indo-Anglian and English. Rate your preference on a three- point scale: Very Well 1, Well 2, a little 3. Put a circle round the number that applies to you)

$\begin{array}{lccc}\text { Text } & \text { Very Well } & \text { Well } & \text { A Little } \\ \text { British Literature } & 1 & 2 & 3 \\ \text { Indian English Literatue } & 1 & 2 & 3 \\ \text { American Literature } & 1 & 2 & 3\end{array}$

[6] Which following poet do you prefer to read and teach most? [Please tick mark] O Robert Frost O William Wordsworth O Nissim Ezekiel

[7] Do you find it easy to teach English through IWE? Yes $(\ldots \ldots \ldots) \quad$ No $(\ldots \ldots \ldots) \quad$ I don't know $(\ldots \ldots \ldots)$

\section{ACKNOWLEDGEMENT}

It is a pleasure to thank in a special word 'Gratitude' all those who helped and encouraged me in the preparation of this paper. I am sincerely grateful to my research guide Dr. R. M. Patil, Associate Professor, Vidya Bharati College, Amravati for playing a major part in completing this paper. His easy manners and accessibility made the task of writing the paper a pleasurable experience.

It is my father Mr. K. T. Thorat, retired Principal, Renukamata Junior College, Gowardhan who has been the main source of my academic career. I am also grateful to my uncle Dr. H. T. Thorat, ex. Director, Govt. V. I. S. \& H. Amravati who helped me out on acquiring the right perspective in the area of Indian English Literature and language teaching. Besides, Mrs. Pratibha S. Thorat, my beloved wife, co-operated and genuinely helped me.

I would like to thank Hon'ble Dr. Devisinghji Shekhawat, Founder and ex. Secretary, Vidya Bharati Shaikshanik Mandal, Amravati and Hon'ble Mrs. Pratibhatai Patil, President of India, and Ex. President of Vidya Bharati Shaikshanik Mandal, Amravati who encouraged me indirectly to complete and submit this paper. I am equally indebted to Dr. G. P. Patil, Principal, S. S. S. K. R. Innani College, Karanja Lad, Dist. Washim.

\section{REFERENCES}

[1] Abidi, S. Z. H. (1978). Studies in Indo Anglian poetry. Bareilly: Prakash Book Depot.

[2] Das, Bijay Kumar. (1982). Modern Indo-English poetry. Bareilly: Prakash Book Depot.

[3] Ediger, Marlow and Bhaskara Rao, Digumarti. (eds.) (2003). Teaching language arts successfully. New Delhi: Discovery Publishing House.

[4] Graddol, David. (2006). English NEXT. London: British Council. 
[5] Gupta, Deepti. (2005). ELT in India: a brief historical current overview. Asian EFL Journal. Vol. 7, 12.

[6] Iyengar, K. R. S. (1962). Introduction to Indian writing in English. Bombay: Asia Publishing House.

[7] Jain, Jasbir. (2003). Writers of the Indian diaspora: theory and practice. New Delhi: Rawat Publications, 11-17.

[8] Krishnaswamy, N. and Krishnaswamy, Lalitha. (eds.) (2003). Teaching English. Chennai: Macmillan India Limited.

[9] Kumaravadivelu B. (2008). TESOL methods: Changing tracks, challenging trends. TESOL Quarterly Vol. 40, 59-81.

[10] Kurup, P. K. J. (1991). Contemporary Indian poetry in English. New Delhi: Atlantic Publishers and Distributors.

[11] Lazar, Gillian. (ed.) (1993). Literature and language teaching: a guide for teachers and trainers. England: Cambridge University Press.

[12] Mokashi-Punekar, Shankar. (1978). Theoretical and practical studies in Indo-English literature. Dharwad: Karnatak University.

[13] Mukalel, Joseph C. (ed.) (2003). Psychology of language learning. New Delhi: Discovery Publishing House.

[14] Naik, M. K. (2004). Aspects of Indian writing in English. New Delhi: Macmillan India Ltd., 11-16.

[15] Pandey, Mithilesh K. (1999). Contemporary Indian literature in English, a humanistic perspective. New Delhi: Kalyani Publishers.

[16] Paranjape, Makarand. (ed.) (1993). Indian poetry in English. Madras: Macmillan India Ltd., 1-27.

[17] Ravi, P. S. (2003). Modern Indian fiction. New Delhi: Prestige Books.

[18] Tickoo, M. L. (ed.) (2003). Teaching and learning English. New Delhi: Orient Longman Private Limited.

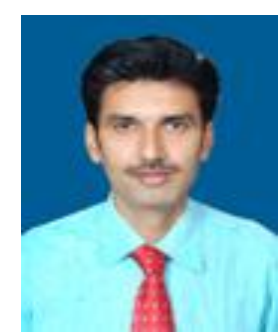

Sandeep K. Thorat born in Akot, the tahsil place in Maharashtra, India on $5^{\text {th }}$ Nov. 1973. He completed his degree of B. A. (Bachelor of Arts) and M. A. (Master of Arts in English) from Sant Gadge Baba Amravati University, Maharashtra, India in 1994 and 1996 respectively. He is the candidate for Ph. D. in the same university. He completed his M. Phil. from Alagappa University, Tamil Nadu, India. His specialization is in English Literature.

He has been working as a head, the department of English since 1998 at S. S. S. K. R. Innani College, Karanja Lad, Washim, Maharashtra, India. He contributed three research papers in online journal www. Languageinindia. com entitled (1) Teaching English as a second language to meets the needs of the learners in rural areas: a challenge. (2) Teaching English through IWE in rural India. (3) Characteristic Indian attitudes in Nissim Ezekiel's poetry. Besides, he is doing Minor Research Project under UGC, New Delhi. 